\title{
Effects of Bank Characteristics on Transmission of Monetary Policy Through Bank Lending Channel in Vietnam
}

\author{
NGUYẼ̃N PHÚC CẢNH \\ University of Economics HCMC \\ phuccanhnguyen.ueh@gmail.com \\ NGUYẼ̃N QUỐC ANH \\ University of Economics HCMC \\ quocanhthuthao@gmail.com \\ NGUYẼ̃N HỒNG QUÂN \\ Đại Dương Commercial Bank - Cà Mau Branch \\ quannh@oceanbank.vn
}

\begin{abstract}
ARTICLE INFO
ABSTRACT

Article history:

Credits from commercial banks influence various economic

Received:

June 27, 2013

Received in revised form

Sep. 03, 2013

Accepted:

Dec. 31,2013

components, such as investment and consumption of durables and changes in monetary policy and therefore, affect the economy through supply of credits by commercial banks. This paper explores transmission of monetary policy through commercial bank lending channel in Vietnam in 2003-2012 by examining reaction of each bank to changes in monetary policy. Authors use the GMM (generalized method of moments) for panel data gathered from financial statements of commercial banks in 2003-2012. Results show that GMM helps detect the existence of bank lending channel in the transmission

Keywords: mechanism in Vietnam, and bank characteristics relating to equity monetary policy, transmission, credit, bank capital, liquidity assets and risk degrees affect their flexibility when responding to changes in monetary policy in the surveyed period.
\end{abstract}

characteristics. 


\section{INTRODUCTION}

\section{a. Necessity of the Research:}

Vietnam's economy, especially its banking system, faced many difficulties after the 1997 global economic crisis. The SBV had changed from a loose monetary policy in 2000-2005 to a tighter one in 2009-2012. According to the traditional economic theory, the monetary policy affects not only growth of credit but also banks' risks. On the other hand, reactions by commercial banks to the monetary policy also produce various effects on the economy. Impacts of the monetary policy on risks and growth of credit differ across banks because of their own operational and business characteristics. From this aspect, research on transmission mechanism of monetary policy to the economy through banks' growth of credit and risks in relation to their characteristics is important to the SBV determination and implementation of monetary policy.

\section{b. Research Objectives:}

The research on reactions by commercial banks as conditioned by their characteristics to the transmission of monetary policy through commercial bank lending channel aims at answering two questions:

- How did the monetary policy affect growth of credit from commercial banks in the years 2004-2012?

- How did characteristics of commercial banks affect impacts of the monetary policy on growth of credit and risks of commercial banks in 2004-2012?

\section{THEORETICAL BASIS AND METHODOLOGY}

\section{a. Monetary Policy and Channels of Transmission:}

- Monetary policy and transmission mechanism:

The monetary policy comprises actions taken by the central bank to influence the money supply or interest rate (de Paula Lico Júnior, 2008). Basically, there are two monetary policies: contractionary and expansionary ones. Tools for implementing the monetary policy include open market operations, reserve requirement and interest rate (Mishkin, 2009). Employing such tools, central banks can influence variables of the economy through various channels of transmission such as interest rate, exchange rate, credit supply and asset prices. According to Mishkin (2009), there are nine channels of transmission, and interest rate is a principal one. Other channels, such as exchange rate and credit supply, are also important ones. 


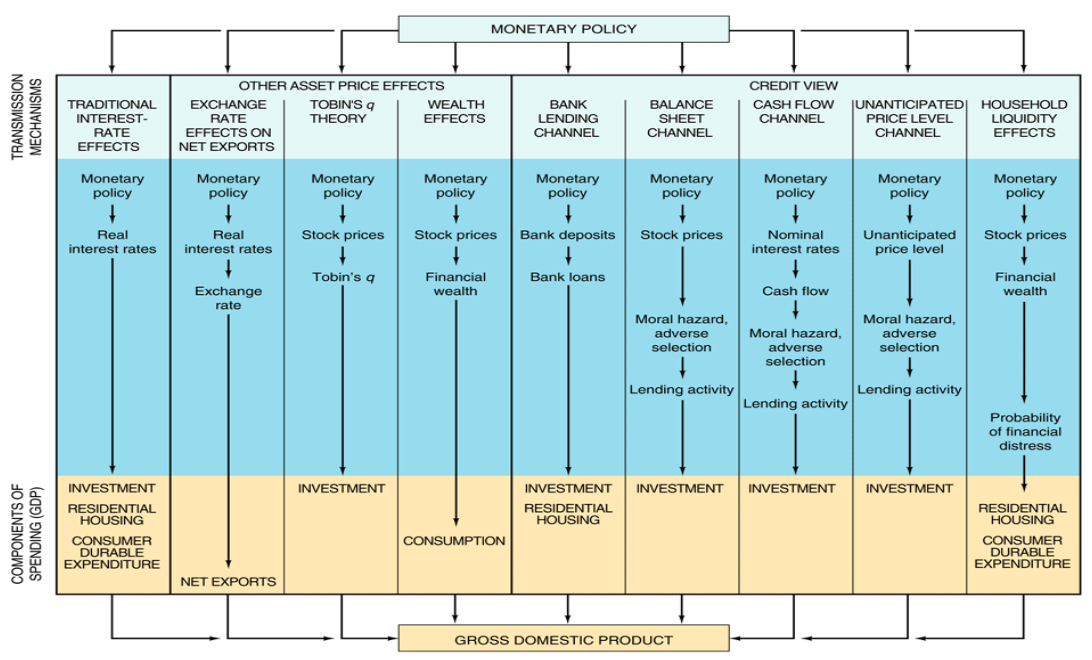

Figure 1: Channels of Monetary Transmission

Source: Mishkin (2009)

In the U.S. for example, the monetary transmission mechanism operates through various channels, including interest rate (Fed fund rate), credit, exchange rate, and asset prices (Kuttner \& Mosser, 2002).

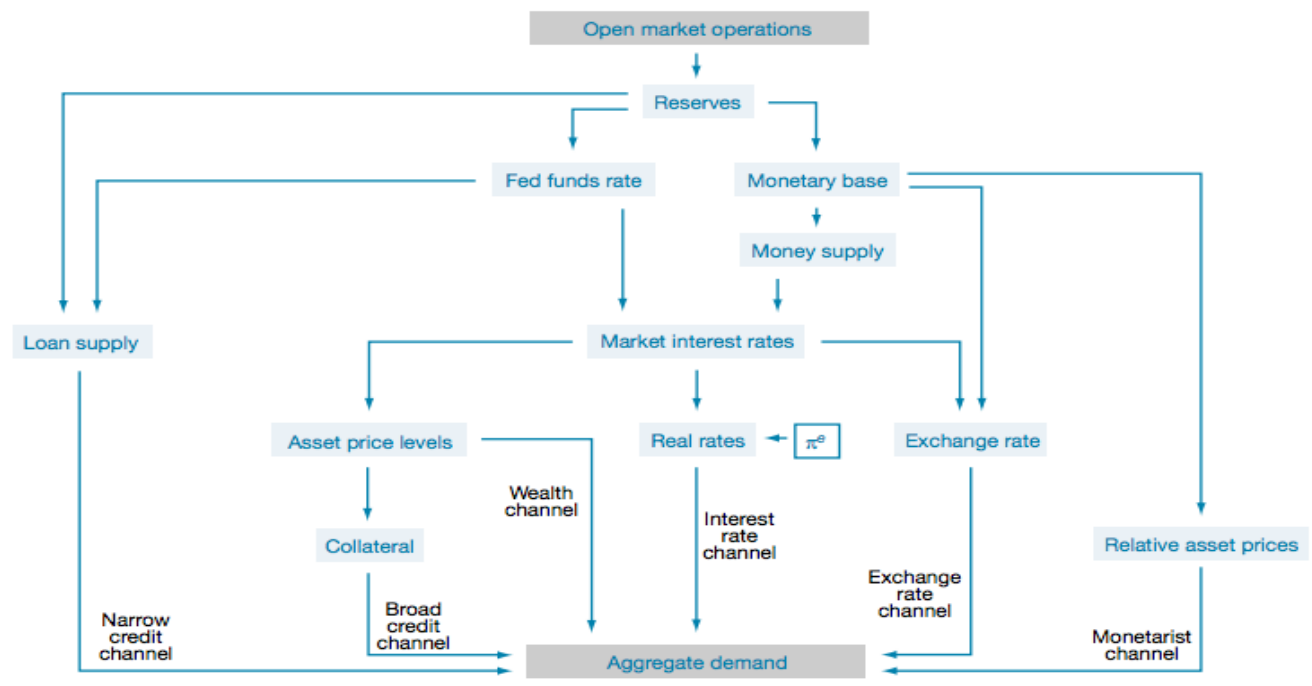

Figure 2: Monetary Policy Transmission

Source: Kuttner \& Mosser (2002) 
In developing countries, the most widely used mechanism is to influence directly the basic money supply thereby affecting the interest rate, credit supply and exchange rate, and controlling inflation rate (Sử \& Vũ, 2008).

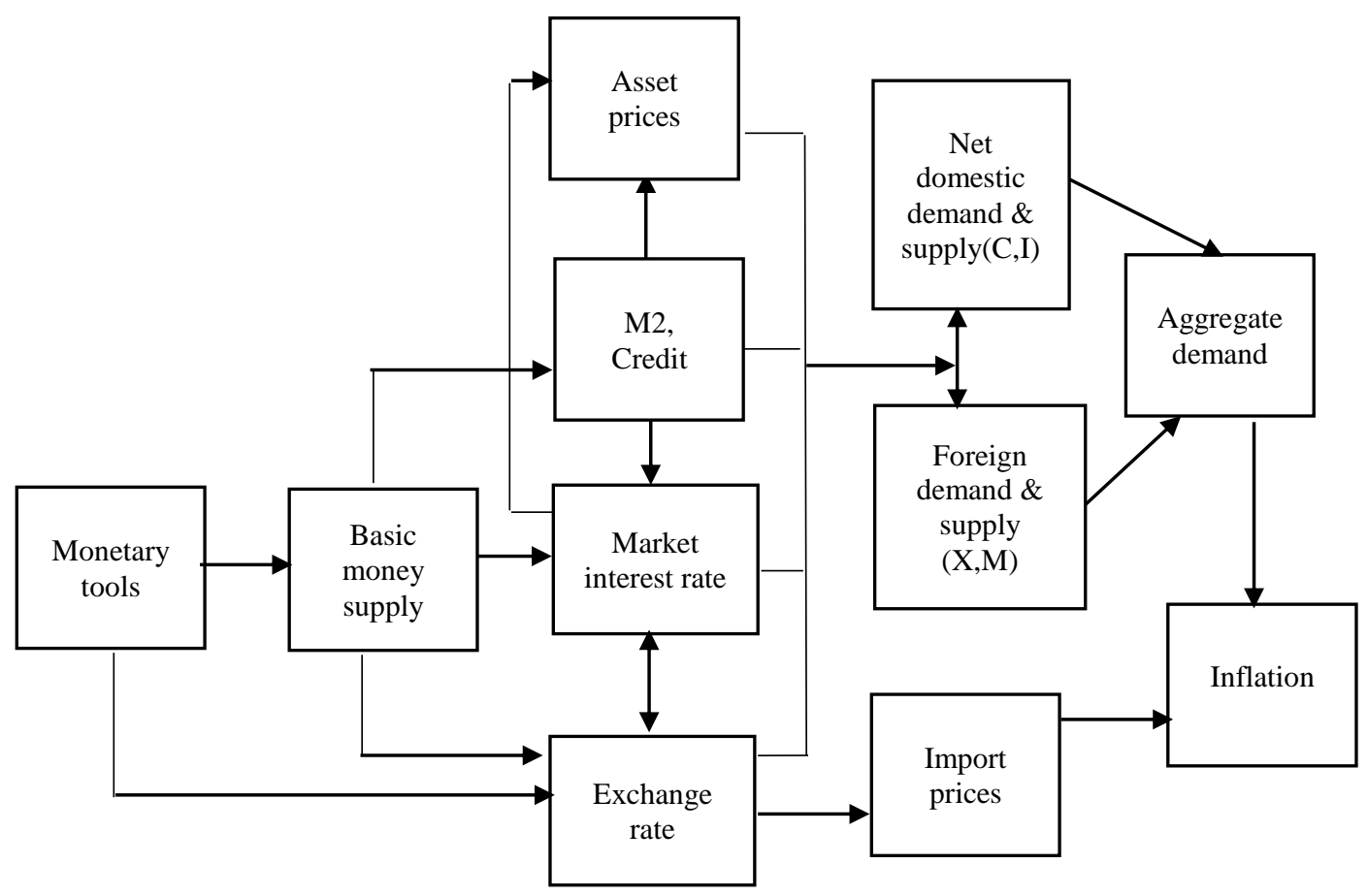

Figure 3: Monetary Policy Transmission in Vietnam

Source: Sử \& Vũ (2008)

Transmission channels of monetary policy are subjects of many researches: De Arcangelis \& Di Giorgio (1999) examine them in Italy; Morsink \& Bayoumi (2001) study Japanese ones; Disyatat \& Vongsinsirikul (2003) analyze the monetary policy and mechanism in Thailand; Poddar, Sab \& Khatrachyan (2006) explore the case of Jordan; Chow (2004) conducts a research in Singapore; Fung (2002) tests for impacts of the monetary policy on East Asian economies; Hùng \& Pfau (2008) study the case of Vietnam; Liu (2011) the Chinese case while Bicchal the Indian one.

Most researches find that the interest rate is an important channel of monetary transmission in most countries. In developing countries where financial markets have not well developed, the bank lending is the principal one. 
- Monetary policy transmission through bank loan supply:

Changes in the monetary policy lead to changes in banks' loan supply, which affect other economic activities (investment, durable expenditure, etc.) (Mishkin, 2009). The monetary policy transmission, however, is affected by characteristics of each bank (Altunbas, Gambacorta \& Marques-Ibanez, 2010).

Angeloni, Kashyap \& Mojon (2003) show that many factors of bank characteristics (equity capital, total assets, liquid asset, and credit risk) affect the monetary policy transmission through the lending channel in Europe. Loutskina \& Strahan (2006), Hirtle (2007), and Altunbas et al. (2009) show that reactions by banks to the monetary policy transmission are determined by their characteristics and therefore growth of credit differs over banks. For example, increased size of the bank provides it with higher lending capacity and changes in the monetary policy will not affect much this capacity or growth of credit (Altunbas, Gambacorta \& Marques-Ibanez, 2010).

When bank's liquidity is stable and its ability to respond effectively to changes in the market, it need not hold too large liquid assets, which allows a high growth of credit. Additionally, improvements in the finance market encourage banks to supply loans to projects in riskier fields (Hänsel \& Krahnen, 2007). Taylor (2009), after examining the 2008 crisis, concluded that the monetary policy was also one of the factors that drove US commercial banks to riskier projects, which brought them to the 2008 financial crisis.

Most researches on the monetary policy transmission employ the VAR model with variables for macro factors and do not examine whether characteristics of commercial banks affect the transmission through bank lending channel. Altunbas, Gambacorta \& Marques-Ibanez (2010) employ GMM model to explore impacts of the monetary policy on the growth of credit and gives full attention to characteristic of each bank and risks it faces. The model they employ is as follows [1]: 


$$
\begin{aligned}
\Delta \ln (\text { Loans })_{i, t}= & \alpha \Delta \ln (\text { Loans })_{i, t-1}+\sum_{j=0}^{1} \partial_{j} \Delta \ln (G D P N)_{k, t-j}+\sum_{j=0}^{1} \beta_{j} \Delta i_{M, t-j} \\
& +\sum_{j=0}^{1} \varphi_{j} \Delta i_{M, t-j} * E D F_{i, t-1}+\sum_{j=0}^{1} \sigma_{j} \Delta i_{M, t-j} * S I Z E_{i, t-1}+\sum_{j=0}^{1} \pi_{j} \Delta i_{M, t-j} \\
& * L I Q_{i, t-1}+\sum_{j=0}^{1} \sigma_{j} \Delta i_{M, t-j} * C A P_{i, t-1}+\omega S I Z E_{i, t-1}+\vartheta L I Q_{i, t-1} \\
& +\mu C A P_{i, t-1}+¥ L L P_{i, t-1}+\lambda E D F_{i, t-1}+\varepsilon_{i, t}
\end{aligned}
$$

Source: Altunbas, Gambacorta \& Marques-Ibanez (2010)

In Vietnam, there were several researches on impacts of the monetary policy on various variables, such as stock market (Nguyễn Thị Bích Loan, 2013), inflation (Nguyễn Trung Kiên, 2013), trade balance (Lại, 2012), exchange rate (Trần, 2012), and growth rate (Phương, 2013), and a study of the impacts of monetary policy transmission on the bank lending channel by Chu (2012). This study also employs a VAR model to measure the monetary policy transmission through the lending channel with such macro variables as inflation rate, foreign exchange reserves, and exchange rate, etc. without mentioning the role of characteristics of each bank in the transmission of monetary policy to the growth of credit and bank risks.

\section{METHODOLOGY}

Realizing the gap in empirical researches on the monetary policy transmission through the bank lending channel in relation to bank characteristics, this research suggests employing the GMM model used by Altunbas, Gambacorta \& MarquesIbanez (2010) to test impacts of the monetary policy on the growth of credit among Vietnamese commercial banks in relation to their characteristics. The GMM model is used for handling the heteroscedasticity caused by the panel data. The testing model takes the following form:

$\Delta \ln (\text { loan })_{\mathrm{i}, \mathrm{t}}=\alpha \Delta \ln (\text { loan })_{\mathrm{i}, \mathrm{t}-1}+\sigma_{2} \Delta \ln (\mathrm{GDP})_{\mathrm{t}-1}+\phi_{1} \Delta \mathrm{i}_{\mathrm{t}}+\phi_{2} \Delta \mathrm{i}_{\mathrm{t}-1}+\varphi_{1} \Delta \mathrm{i}_{\mathrm{t}} * \operatorname{SIZE}_{\mathrm{i}, \mathrm{t}-1}+\varphi_{2} \Delta \mathrm{i}_{\mathrm{t}-}$ ${ }_{1} * \mathrm{SIZE}_{\mathrm{i}, \mathrm{t}-1}+\tau_{1} \Delta \mathrm{i}_{\mathrm{t}} * \mathrm{LIQ}_{\mathrm{i}, \mathrm{t}-1}+\tau_{2} \Delta \mathrm{i}_{\mathrm{t}-1} * \mathrm{LIQ}_{\mathrm{i}, \mathrm{t}-1}+\psi_{1} \Delta \mathrm{i}_{\mathrm{t}} * \mathrm{CAP}_{\mathrm{i}, \mathrm{t}-1}+\psi_{2} \Delta \mathrm{i}_{\mathrm{t}-1} * \mathrm{CAP}_{\mathrm{i}, \mathrm{t}-1}+¥_{2} \mathrm{SIZE}_{\mathrm{i}, \mathrm{t}-}$ ${ }_{1}+\omega_{1} \mathrm{LIQ}_{\mathrm{i}, \mathrm{t}-1}+\lambda_{1} \mathrm{CAP}_{\mathrm{i}, \mathrm{t}-1}+\mu_{1} \mathrm{LLP}_{\mathrm{i}, \mathrm{t}-1}+\varepsilon_{\mathrm{i}, \mathrm{t}}$

Variables included in the model are similar to the ones in the original model. First of all, the growth of credit is affected by the monetary policies of central banks, through 
the interest rate, to be precise. A lower interest rate will encourage commercial banks to supply more loans while the public are ready to get more loans for consumption of business, which make credit supplied increase (Bernanke \& Gertler, 1995).

Variables for bank characteristics, macroeconomic management and interest rate allowed a lag of one year (t-1) to be compliant with macroeconomic theories because the monetary policy always has a time lag in influencing other variables (Ehrmann \& Worms, 2004). $\Delta \ln (\text { loan })_{i, t-1}$ along with other variables is integrated into interest rate and a lag of 1 is used in the model to control endogenous error of the model.

Data are collected from financial statements and annual reports by commercial banks in Vietnam (five state-owned banks, 34 commercial joint stock ones, five foreign ones, and four banking joint ventures, up to Dec. 31, 2012) along with secondary data about interest rates, money supply and growth rates in 2004-2012. The data are used for testing impacts of the monetary policy on bank's growth of credit and risks in relation to characteristics of each bank.

Table 1: Variables and Expected Correlations

\begin{tabular}{|c|c|c|}
\hline Variable & $\begin{array}{c}\text { Expected } \\
\text { correlation }\end{array}$ & Explanation \\
\hline$\Delta \ln (\operatorname{loan})_{\mathrm{i}, t-1}$ & + & $\begin{array}{l}\text { Growth in the previous year produces momentum for credit growth } \\
\text { in the next year (endogenous error) (Altunbas et al., 2009) }\end{array}$ \\
\hline$\Delta \ln (\mathrm{GDP})_{\mathrm{t}}$ & + & $\begin{array}{l}\text { Control variable: Economic growth makes demand for credit } \\
\text { increase, and the credit growth in the next year is higher (Kashyap } \\
\text { et al., 1993) }\end{array}$ \\
\hline$\Delta \mathrm{i}_{\mathrm{t}}$ & - & $\begin{array}{l}\text { Variable for monetary policy: Increased interest rat reduces the } \\
\text { credit growth (Altunbas, Gambacorta \& Marques-Ibanez, 2010; } \\
\text { Rajan, 2005; and Bernanke \& Gertler, 1995). }\end{array}$ \\
\hline$\Delta \mathrm{i}_{\mathrm{t}-1}$ & - & $\begin{array}{l}\text { Increased interest rat reduces the credit growth (Altunbas, } \\
\text { Gambacorta \& Marques-Ibanez, 2010; Rajan, 2005; and Bernanke } \\
\text { \& Gertler, 1995). }\end{array}$ \\
\hline $\mathrm{SIZE}_{\mathrm{i}, \mathrm{t}-1}$ & $+/-$ & $\begin{array}{l}\text { When the bank's size increases, its growth rate may be higher or } \\
\text { lower, thereby affecting the transmission of monetary policy } \\
\text { through bank lending channel (Kashyap \& Stein, 1995). }\end{array}$ \\
\hline
\end{tabular}




\begin{tabular}{|c|c|c|}
\hline $\mathrm{LIQ}_{\mathrm{i}, \mathrm{t}-1}$ & + & $\begin{array}{l}\text { Higher liquidity ratio in the previous year helps expend credit } \\
\text { supply in the nest year (Stein, 1998) and affects the transmission of } \\
\text { monetary policy through bank lending channel. }\end{array}$ \\
\hline $\mathrm{CAP}_{\mathrm{i}, \mathrm{t}-\mathrm{1}}$ & + & $\begin{array}{l}\text { An increasing ratio of equity capital in the previous year encourages } \\
\text { increases in credit supply in the next year (Van den Heuvel, 2002), } \\
\text { thereby affecting the transmission of monetary policy through bank } \\
\text { lending channel. }\end{array}$ \\
\hline $\operatorname{LLP}_{\mathrm{i}, \mathrm{t}-1}$ & - & $\begin{array}{l}\text { High credit risk in the previous year limits increases in credit supply } \\
\text { in the next year (Kishan \& Opiela, 2000). The variable for risk used } \\
\text { in this research is ratio of loan loss provision: the higher the ratio, } \\
\text { the bigger the bank risk. }\end{array}$ \\
\hline
\end{tabular}

\section{RESULTS AND DISCUSSIONS}

\section{a. Monetary Policy and Credit Growth in the Banking System:}

An outline of relationship between the monetary policy and credit growth in 20042012 could help estimate impacts of the policy on the banking system. Inter-bank offered rate (Vnibor) stayed at a low level in 2004-2007 (loose monetary policy), rose quickly in 2008 (tight policy), fell sharply in 2009 (loose policy and demand stimulus package), and then rose and stayed at a high level in 2010-2011 (tight policy). In 2012, a loose policy was adopted and the Vnibor rate fell, especially in the last months of 2012.

The monetary policy is more visible in the growth of money supply (M2). In the years 2004-2007, the growth of money supply in Vietnam was high (over 30\% per year on average) and increased over years. In 2008, the growth decreased sharply to $20 \%$ per year. In 2009 it rose again and then fell drastically in 2011 and 2012. In this period, the credit growth was always much higher than the target set by the SBV.

Table 2: Vietnam's Credit Growth in 2004-2012

\begin{tabular}{lllllllllll}
\hline Indicator & Year & 2004 & 2005 & 2006 & 2007 & 2008 & 2009 & 2010 & 2011 & 2012 \\
\hline Credit & Target & 25 & 25 & $18-20$ & $17-21$ & 30 & $21-23$ & 25 & 20 & $15-17$ \\
$(\%)$ & Realized & 41.6 & 31.1 & 25.4 & 53.9 & 25.4 & 37.5 & 31.2 & 14.4 & 6.45 \\
\hline
\end{tabular}

Source: SBV (2013)

In 2011-2012, the credit growth was much lower than the SBV target. In 2012 in particular, the growth was only $6.45 \%$ compared with the planned level of $15 \%-17 \%$. This reverse implies that the demand for bank loan was much lower than that in previous 
periods. A close examination of relationships between interest rate, growth of money supply and credit growth detects a negative relationship between the Vnibor and the other two variables in the whole surveyed period.

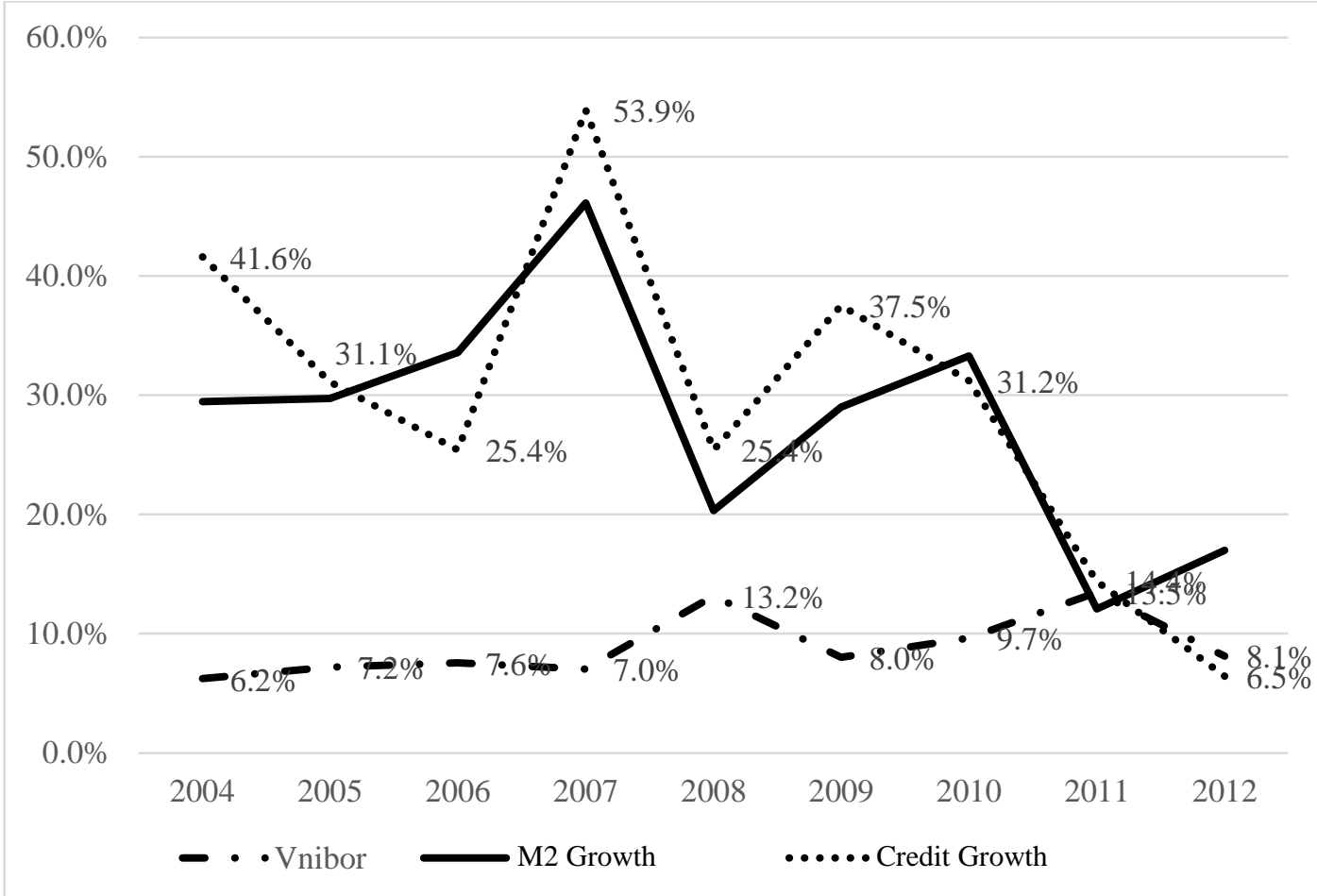

Figure 4: Vnibor, M2 Growth and Credit Growth in Vietnam in 2004-2012

Source: ADB (2012), SBV (2013)

\section{b. Model Testing:}

Based on the aforementioned findings about the monetary policy and credit growth, authors started studying the transmission of monetary policy through the lending channel as influenced by characteristics of each bank in GMM model. To test features of data, heteroscedasticity and auto-correlation in the model, the authors used a fixed effect regression model. The results showed that R2 is very high (99.18\%) but the model contains heteroscedasticity. Therefore, the use of GMM model is more suitable.

At first, the GMM model is used with all variables (GMM 1). 
Table 3: Results of GMM 1

\begin{tabular}{lcc}
\hline \multicolumn{1}{c}{ Variable } & Expected correlation & GMM 1 Results \\
\hline$\Delta \ln (\text { loan })_{\mathrm{i}, \mathrm{t}-1}$ & + & $0.529^{* *}$ \\
$\Delta \ln (\mathrm{GDP})_{\mathrm{t}}$ & + & 0.309 \\
$\Delta \mathrm{i}_{\mathrm{t}}$ & - & $0.067^{* *}$ \\
$\Delta \mathrm{i}_{\mathrm{t}-1}$ & - & $0.111^{*}$ \\
$\mathrm{SIZE}_{\mathrm{i}, \mathrm{t}-1}$ & $+/-$ & 0.241 \\
$\mathrm{LIQ}_{\mathrm{i}, \mathrm{t}-1}$ & + & $4.293^{*}$ \\
$\mathrm{CAP}_{\mathrm{i}, \mathrm{t}-1}$ & + & $2.86^{* *}$ \\
\hline
\end{tabular}

Notes: *,**, *** denotes significance level of $1 \%, 5 \%$, and $10 \%$ respectively

Source: GMM Regression results

GMM1 results show that most variables affect the monetary policy transmission through lending channel in Vietnam in 2003-2012 and this relationship is compliant with grounded theories. The variable "interest rate" for monetary policy, however, has an interaction contrary to the theoretical framework. Theoretically, a contractionary policy (increased base rate) reduce the growth of credit in commercial banks but the model shows a reverse correlation although coefficients are rather small (0.067 and 0.111 respectively). Meanwhile, of instrumental variables reflecting correlations of the monetary policy with the bank lending channel, only LIQ and CAP are statistically significant and SIZE is not, which shows that the size of bank does not much influence impacts of the monetary policy through the bank lending channel while characteristics of banks, such as equity capital and liquidity produce strong impacts. Additionally, the variable LLP is an instrumental variable when applying the model, but GMM could not define its value, which implies that commercial banks in 2003-2012 did not pay full attention to risks involved in credit growth when responding to shocks caused by the monetary policy.

To check robustness of the model, the first-order Arellano-Bond test is used and it is statistically significant, implying correlation, or lag of the monetary policy, which is compliant with the theoretical framework, and in the model the first-order lag is used. Meanwhile, the second-order Arellano-Bond test is not statistically significant; therefore, the use of a first-order lag is totally suitable. Moreover, the use of Sargan test 
for checking the robustness of the model yields no statistical significance, which implies that the model is appropriate. In short, the model employed is appropriate and reliable (F test produces a highly statistical significance).

Table 4: Results from Models

\begin{tabular}{|c|c|c|c|c|c|c|c|c|}
\hline \multirow{2}{*}{$\begin{array}{c}\text { Model } \\
\text { Variable }\end{array}$} & \multicolumn{2}{|c|}{$\begin{array}{l}\text { Fixed-effect OLS } \\
\text { regression model }\end{array}$} & \multicolumn{2}{|c|}{ GMM 1} & \multicolumn{2}{|c|}{ GMM 2} & \multicolumn{2}{|c|}{ GMM 3} \\
\hline & Slope value & $\begin{array}{l}\text { P-test } \\
\text { value }\end{array}$ & Slope value & $\begin{array}{l}\text { P-test } \\
\text { value }\end{array}$ & $\begin{array}{l}\text { Slope } \\
\text { value }\end{array}$ & $\begin{array}{l}\text { P-test } \\
\text { value }\end{array}$ & $\begin{array}{l}\text { Slope } \\
\text { value }\end{array}$ & $\begin{array}{l}\text { P-test } \\
\text { value }\end{array}$ \\
\hline \multicolumn{9}{|l|}{$\begin{array}{l}\text { Independent: } \\
\Delta \ln (\text { loan }) \mathrm{i}, \mathrm{t}\end{array}$} \\
\hline \multicolumn{9}{|l|}{ Dependent } \\
\hline$\Delta \ln ($ loan $) \mathrm{i}, \mathrm{t}-1$ & 1.1 & 0.000 & 0.529 & 0.024 & 0.530 & 0.023 & 0.887 & 0.000 \\
\hline$\Delta \ln (\mathrm{GDP})_{\mathrm{t}-1}$ & -5.7 & 0.012 & 0.265 & 0.393 & 0.322 & 0.228 & $\mathrm{n} / \mathrm{a}$ & \\
\hline$\Delta \mathrm{i}_{\mathrm{t}}$ & $251,361.7$ & 0.739 & 0.067 & 0.083 & 0.074 & 0.028 & 0.097 & 0.010 \\
\hline$\Delta \mathrm{i}_{\mathrm{t}-1}$ & $2,536,205.0$ & 0.002 & 0.113 & 0.007 & 0.1103 & 0.0304 & 0.104 & 0.003 \\
\hline$\Delta \mathrm{i}_{\mathrm{t}} * \mathrm{SIZE}_{\mathrm{i},-1}$ & 0.0 & 0.000 & 0.000 & 0.711 & $\mathrm{n} / \mathrm{a}$ & & $\mathrm{n} / \mathrm{a}$ & \\
\hline$\Delta \mathrm{i}_{\mathrm{t}-1} * \mathrm{SIZE}_{\mathrm{i}, \mathrm{t}-1}$ & 0.0 & 0.000 & 0.000 & 0.243 & 0.000 & 0.266 & $\mathrm{n} / \mathrm{a}$ & \\
\hline$\Delta \mathrm{i}_{\mathrm{t}} * \mathrm{LIQ}_{\mathrm{i}, \mathrm{t}-1}$ & $119,741.7$ & 0.937 & -0.203 & 0.013 & -0.208 & 0.009 & -0.280 & 0.003 \\
\hline$\Delta \mathrm{i}_{\mathrm{t}-1} * \mathrm{LIQ}_{\mathrm{i}, \mathrm{t}-1}$ & $-1,779,088.0$ & 0.256 & -0.292 & 0.000 & -0.290 & 0.000 & -0.304 & 0.001 \\
\hline$\Delta \mathrm{i}_{t} * \mathrm{CAP}_{\mathrm{i}, \mathrm{t}-1}$ & $-965,074.1$ & 0.610 & -0.205 & 0.021 & -0.216 & -0.010 & -0.227 & 0.007 \\
\hline$\Delta \mathrm{i}_{\mathrm{t}-\mathrm{1}} * \mathrm{CAP}_{\mathrm{i}, \mathrm{t}-1}$ & $-3,731,707.0$ & 0.100 & -0.073 & 0.508 & -0.068 & 0.533 & $\mathrm{n} / \mathrm{a}$ & \\
\hline SIZE $_{\mathrm{i}, t-1}$ & 0.3 & 0.000 & 0.242 & 0.319 & 0.222 & 0.346 & $\mathrm{n} / \mathrm{a}$ & \\
\hline $\operatorname{LIQ}_{\mathrm{i}, \mathrm{t}-1}$ & $19,200,000.0$ & 0.361 & 4.293 & 0.000 & 4.332 & 0.000 & 5.399 & 0.000 \\
\hline $\mathrm{CAP}_{\mathrm{i}, t-1}$ & $33,300,000.0$ & 0.229 & 2.866 & 0.048 & 2.886 & 0.045 & 2.405 & 0.004 \\
\hline $\operatorname{LLP}_{\mathrm{i}, \mathrm{t}-1}$ & $118,000,000.0$ & 0.331 & $\mathrm{n} / \mathrm{a}$ & & $\mathrm{n} / \mathrm{a}$ & & -2.458 & 0.675 \\
\hline $\mathrm{R} 2$ & 0.9918 & & & & & & & \\
\hline F-test & 432.0 & 0.000 & 77.850 & 0.000 & 89.90 & 0.000 & 133.170 & 0.000 \\
\hline \multirow[t]{2}{*}{$\begin{array}{l}\text { F-test for } \\
\text { heteroscedasticity }\end{array}$} & & 0.7920 & $\begin{array}{l}\text { First-order } \\
\text { Arellano-Bond } \\
\text { test }\end{array}$ & 0.000 & & 0.000 & & 0.000 \\
\hline & & & $\begin{array}{l}\text { Second first- } \\
\text { order Arellano- } \\
\text { Bond test }\end{array}$ & 0.410 & & 0.438 & & 0.597 \\
\hline
\end{tabular}




\begin{tabular}{lccc}
$\begin{array}{l}\text { Inflation factor } \\
\text { Sargan test }\end{array}$ & 0.218 & 0.241 & 0.690 \\
$\begin{array}{l}\text { Sargan test } \\
\text { excluding } \\
\text { group }\end{array}$ & 0.436 & 0.478 & 0.820 \\
$\begin{array}{l}\text { Test for } \\
\text { exogeneity }\end{array}$ & 0.039 & 0.036 & 0.168 \\
\hline
\end{tabular}

Source: Results of regression with Stata

Thus, GMM1 shows that in the years 2003-2012 in Vietnam, characteristics of commercial banks did affect transmission of monetary policy through the bank lending channel in which:

Total asset: The size of total asset of the bank does not influence much the transmission of monetary policy through the bank lending channel. This can be explained by the fact that Vietnam enjoyed high growth rates along with many risks in the period 2003-2012 and the size of banks increased over years.

But the SBV, when implementing the monetary policy, always sets limit on banks' credit growth, which causes almost no correlation between the credit growth and total assets of the banks.

Table 5: Limits on Credit Growth in Vietnam in 2004-2012

\begin{tabular}{lcccccccccc}
\hline Indicator & & $\mathbf{2 0 0 4}$ & $\mathbf{2 0 0 5}$ & $\mathbf{2 0 0 6}$ & $\mathbf{2 0 0 7}$ & $\mathbf{2 0 0 8}$ & $\mathbf{2 0 0 9}$ & $\mathbf{2 0 1 0}$ & $\mathbf{2 0 1 1}$ & $\mathbf{2 0 1 2}$ \\
\hline $\begin{array}{l}\text { Limit on } \\
\text { growth }(\%)\end{array}$ & credit & 25 & 25 & $18-20$ & $17-21$ & 30 & $21-23$ & 25 & 20 & $15-17$ \\
\hline
\end{tabular}

Source: SBV

Equity capital: It has a positive relationship with the transmission of monetary policy through the bank lending channel. Commercial banks with high equity ratios have better ability to absorb changes in the monetary policy.

Liquid asset: It has a positive effect on the credit growth. Banks with bigger liquid assets have better reactions to monetary policy shocks.

Loan loss provision: The results show that Vietnamese commercial banks failed to pay full attention to risk provisions when reacting to changes in the monetary policy.

The GMM1 results show that the bank total assets do not affect much the transmission of monetary policy through the bank lending channel. To find a model with better significance, authors remove variables on total assets in GMM2 model, and then remove 
variables for GDP and lag between $i$ and bank's equity capital to develop the GMM3 model.

The results show that both contracted models GMM2 and GMM3 produce higher statistical significance with higher F-test value. In the mean time, the significances of independent variables are also higher while tests concerning robustness of models still yield significant results. The three models indicate that characteristics of commercial banks have effects on transmission of monetary policy through the bank lending channel and all of these characteristics are statistically significant and appropriate. However, the overall correlation between interest rate and credit growth has a negative relationship with the theoretical framework. To avoid incorrect assessments, the authors measure the correlation between interest rate and credit growth using one-year lags.

Table 6: Coefficient of correlation between interest rate and credit growth

\begin{tabular}{lccc}
\hline \multicolumn{1}{c}{ Correlation coefficient } & $\Delta \ln (\mathbf{l o a n}))_{\mathbf{i}, \mathbf{t}}$ & $\Delta \mathbf{i}_{\mathbf{t}}$ & $\Delta \mathbf{i}_{\mathbf{t}-\mathbf{1}}$ \\
\hline$\Delta \ln (\text { loan })_{\mathrm{i}, \mathrm{t}}$ & 1 & -0.252208 & -0.079508 \\
$\Delta \mathrm{i}_{\mathrm{t}}$ & -0.252208 & 1 & -0.64144 \\
$\Delta \mathrm{i}_{\mathrm{t}-1}$ & -0.079508 & -0.64144 & 1 \\
\hline
\end{tabular}

Source: Measurement of correletion coefficients between three variables with Stata 12

The results show that the correlation coefficients between the base rate and credit growth are negative (but these coefficients are very small), and this is compliant with the theoretical framework. Thus, the research detects the following exploratory findings:

- The bank lending channel does exist in the transmission of monetary policy in Vietnam.

- Characteristics of commercial banks that have impacts on the transmission of monetary policy through the lending channel are equity capital and bank size.

- Commercial banks in the 2004-2012 period did not pay attention to risks when reacting to external shocks.

\section{CONCLUSION AND POLICY IMPLICATIONS}

\section{a. Conclusions:}

Using the GMM, our research identifies impacts of variables concerning characteristics of commercial banks (capital, liquidity and risk) on the transmission of monetary policy through the bank lending channel in the years 2003-2012. The research 
also produces findings relating to the mechanism for monetary policy transmission through lending channel:

- Commercial banks with higher equity ratios are more flexible in reacting to monetary policy shocks and therefore gain better growth of credit.

- Commercial banks with higher liquidity ratios more flexible in reacting to monetary policy shocks.

- Total assets and loan loss provision have no correlation with the monetary policy transmission through the bank lending channel in Vietnam in 2003-2012. This finding implies that commercial banks did not pay attention to risks when their credit supply increases. Additionally, limits on bank credit growth were set by the SBV without caring about their size.

- GMM model proves to be robust and appropriate to panel data.

\section{b. Limitations and Directions for Future Researches:}

- The model does not include macro variables and data employed are still limited, so the correlation between the base rate and credit growth is somehow different from theoretical framework.

- The research fails to measure impact of the credit growth on other variables to determine the overall effect of the monetary policy.

\section{c. Policy Implications:}

Based on research findings, the authors suggest that commercial banks should pay attention to the following aspects to ensure flexible and effective responses to changes in the monetary policy.

- Re-examining macroeconomic factors, market demand and the bank's size and ability to make an appropriate policy on credit growth.

- Commercial banks should not pursue the credit growth at any cost because it may lead to various risks and reduce flexibility in responding to macro shocks. The model results show that commercial banks did not pay attention to risk when increasing the credit supply and this might be a cause for current troubles in the banking system.

- Managing the liquidity risk should be of top priority to avoid loss of liquid assets when facing shocks that can lead to bankruptcy and improve the bank flexibility in dealing with macroeconomic shocks. 
- Management of credit risk: In the years 2003-2010, commercial banks with high credit growth rates only paid attention to profit instead of credit risk, which led to potential risks and difficulties for the whole banking system in the 2010-2012 period.

- Commercial banks should increase their equity capital to ensure their flexibility and protection against macroeconomic shocks. One of measures to achieve this aim is to secure stable and long-term sources of capital and avoid cross ownership among banks. The banks, therefore, can give priority to increasing the retained profit, issuing new shares to local or foreign markets (this measure is not viable at this moment), and issuing individual shares to strategic investors.

- Since the SBV's role is the agency responsible for managing and implementing the monetary policy, it should determine the ability to absorb and deal with shocks of each commercial bank in order to select the most appropriate monetary instruments instead of using one-size-fits-all method because this approach may cause difficulties for small banks with poor responses to monetary policy shocks.

- The SBV may classify commercial banks according to their capital, liquid assets and credit risks to apply appropriate monetary instruments.

- The SBV may help commercial banks improve their financial strength to secure high equity ratios, thereby reducing losses caused by macroeconomic shocks

\section{Notes:}

[1] Loan (outstanding loans), GDPN (nominal GDP), i (base rate), EDF (Moody's EDF credit measures), SIZE (bank size), LIQ (liquidity ratio), CAP (equity ratio), LLP (loan loss provision).

\section{References}

Aballey, F. B. (2009), Bad Loan Portfolio: A Case of ADB, ADB.

ADB (2012), Key Indicators for Asia and the Pacific 2012, ADB.

Altunbas, Y., L. Gambacorta \& D. Marques-Ibanez (2009), "Securitisation and the Bank Lending Channel", European Economic Review, forthcoming.

Altunbas, Y., L. Gambacorta \& D. Marques-Ibanez (2010), "Bank Risk and Monetary Policy”, Journal of Financial Stability 6, pp. 121-129.

Angeloni, I., A.K. Kashyap \& B. Mojon (2003), Monetary Policy Transmission in the Euro Area, Cambridge University Press.

Bernanke, B. \& M. Gertler (1995), "Inside the Black Box: The Credit Channel of Monetary Policy Transmission”, Journal of Economic Perspective, Vol. 9, pp. 27-48. 
Bicchal, M. (2010), “Monetary Policy and Inflation in India: A Structural VAR Analysis", Artha Vijnana, Vol. 53, No.3. pp. 230-261.

Borio, C., C. Furfine \& P. Lowe (2001), "Procyclicality of the Financial System and Financial Stability: Issues and Policy Options", BIS Papers, No. 1.

Capasso, S. \& G. Mavrotas (2010), "Loan Processing Costs, Information Asymmetries and the Speed of Technology Adoption”, Economic Modelling 27, pp. 358-367.

Chow, H. K. (2004), “A VAR Analysis of Singapore's Monetary Transmission Mechanism”, SMU Economics and Statistics Working Paper Series, Singapore Management University.

Chu Khánh Lân (2012), "Nghiên cứu thực nghiệm về truyền dẫn CSTT qua kênh tín dụng tại VN", Ngân hàng, No. 13, 2012, pp.17-22.

De Arcangelis, G. \& G. Di Giorgio (1999), Monetary Policy Shocks and Transmission in Italy A VAR Analysis, Monetary and Economic Department.

de Paula Lico Júnior, R. (2008), Dictionary of Financial and Business Terms, McGraw -Hill.

Disyatat, P. \& P. Vongsinsirikul (2003) "Monetary Policy and the Transmission Mechanism in Thailand", Journal of Asian Economics, vol. 14(3), pp. 389-418.

Ehrmann, M., \& A. Worms (2004), “Bank Networks and Monetary Policy Transmission”, Journal of the European Economic Association 2 (6), pp. 1148-1171 (MIT Press).

Foos, D., L. Norden \& M. Weber (2010), "Loan Growth and Riskiness of Banks", Journal of Banking \& Finance 34, pp. 2929-2940

Fung, Ben S.C. (2002), A VAR Analysis of the Effects of Monetary Policy in East Asia, Monetary and Economic Department, September 2002.

Gambacorta, L. (2005), "Inside the Bank Lending Channel”, European Economic Review 49, pp. $1737-1759$.

Glen, J. \& C. Mondragón-Vélez (2011), "Business Cycle Effects on Commercial Bank Loan Portfolio Performance in Developing Economies", Review of Development Finance 1, pp. 150-165.

Hänsel, D.N. \& J.P. Krahnen (2007), "Does Credit Securitization Reduce Bank Risk? Evidence from the European CDO Market”, Working Paper, Frankfurt/Main.

Hirtle, B. (2007), “Credit Derivatives and Bank Credit Supply”, Staff Report no. 276, Federal Reserve Bank of New York

Hung, L.V. \& W.D. Pfau (2008), "VAR Analysis of the Monetary Transmission Mechanism in Vietnam", Applied Econometrics and International Development, Vol. 9, No. 1, pp. 165-179.

Kayshap, A. \& J. Stein (1994), “The Impact of Monetary Policy on Bank Balance Sheets”, NBER Working Papers, pp. 4821.

Kishan, R.P. \& T.P. Opiela (2000), "Bank Size, Bank Capital and the Bank Lending Channel”, Journal of Money, Credit and Banking 32, pp. 121-141. 
Kuttner K.N. \& P.C. Mosser (2002), "The Monetary Transmission Mechanism: Some Answers and Further Questions", BIS papers No 12.

Lại Thị Ngọc Châm (2012), Chính sách điều hành tỉ giá và cán cân thuong mại của VN: Thục trạng và giải pháp, Master thesis, UEH.

Liu, Xiaonan (2011) "Monetary Transmission Mechanism in China", doctorate thesis, University of Hong Kong

Loutskina, E. \& P.E. Strahan (2006), "Securitization and the Declining Impact of Bank Finance on Loan Supply: Evidence from Mortgage Acceptance Rates”, NBER Working Paper No. 11983.

Mishkin, F.S. (2009), The Economics of Money, Banking and Financial Markets, McGraw-Hill, 9th edition.

Morsink, J., \& T. Bayoumi (2003), “A Peek Inside the Black Box: The Monetary Transmission Mechanism in Japan”, IMF Staff Papers Vol. 48, No. 1.

Nguyễn Trung Kiên (2013), "Kiềm chế lạm phát với sự phối hợp CSTT và chính sách tài khoá", Nghiên cúu tài chính kế toán, No 2, 2013, pp. 5-7, 23.

Nguyễn Thị Bích Loan (2013), “Tác động của CSTT đối với hoạt động của thị trường chứng khoán TP.HCM”, Kinh tế \& phát triển, No 2, 2013, pp. 34-38.

Nguyễn Thị Ngọc Trang (2012), Lạm phát và hành vi giá cả trong hoạch định CSTT tại VN, a research project supported by UEH.

Phương Ngọc (2013), “Các nước phát triển và đang phát triển nới lỏng CSTT để hỗ trợ thị trường”, Thuế nhà nước, No 9+10, 2013, pp. 26-27.

Poddar, T., R. Sab \& H. Khachatryan (2006), "The Monetary Transmission Mechanism in Jordan”, IMF Working Papers 06/48, IMF.

Stein, J.C. (1998), “An Adverse-Selection Model of Bank Asset and Liability Management with Implications for the Transmission of Monetary Policy", RAND Journal of Economics 29 (3), pp. 466-486.

Sử Đình Thành \& Vũ Thị Minh Hằng (2008), Nhập môn tài chính tiền tệ, Đại học Quốc gia TP.HCM.

Taylor, J.B. (2009), "The Financial Crisis and the Policy Responses: An Empirical Analysis of What Went Wrong”, National Bureau of Economic Research Working paper, pp. 14631.

Trần Ngọc Thơ (2012), Nghiên cưu so thảo về phá giá tiền tệ và một số khuyến nghị chính sách cho $V N$, a research project supported by UEH.

Van den Heuvel, S.J. (2002), “Does Bank Capital Matter for Monetary Transmission?”, Economic Policy Review, May, pp. 260-266. 